\title{
Studiemiljøundersøgelse som empowerment
}

Hanne Dauer Keller, cand.psych., ph.d., lektor, Institut for Laring og Filosofi, Aalborg Universitet.

Annie Aarup Jensen, cand.mag., ph.d., lektor, Institut for Laring og Filosofi, Aalborg Universitet.

\section{Reviewet artikel}

Denne artikel fokuserer på det metodemæssige $i$ at arbejde med studiemiljø og studiemiljøundersøgelser i en kvalitativ, procesorienteret form, der står $i$ kontrast til de traditionelle kvantitative metoder. En alternativ organisering med de studerende som ansvarlige aktører gav andre, mere nuancerede datatyper og aktiverede de studerende i forhold til at påvirke eget studiemiljø.

\section{Indledning}

I de senere år er der kommet en række politiske aftaler om jævnlig evaluering af arbejds- og studiemiljøerne på landets uddannelsesinstitutioner. Disse vurderingsdata danner baggrund for udvikling af uddannelsesinstitutionerne generelt og studiemiljøet specifikt. Typisk gennemføres evalueringerne efter en top-down-styret proces, hvor undersøgelsen designes fra centralt hold, bearbejdes og rapporteres i udvalgte delrapporter til beslutningstagere på forskellige niveauer i organisationen, som herefter vurderer resultaterne og beslutter sig for nogle handlinger. Udgangspunktet er en teknisk-rationel organisationsforståelse, der ser læring som planlagt ændring, hvor der sker en ændring af systemet gennem en proces, hvor problemer afsøges, årsager findes, løsninger formuleres, og handlinger implementeres (Jacobsen \& Thorsvik, 2008). De deltagende studerende er repræsenteret i de besluttende organer og har derfor som samlet gruppe en vis indflydelse på processen, mens den enkelte ikke har direkte indflydelse på design, fortolkning og handlingsforslag.

I mange år har denne type vurderinger fundet sted på landets arbejdspladser som "arbejdspladsvurderinger", "trivselsmålinger", "medarbejdertilfredshedsundersøgelser" osv. Det er fra dette arbejde kendt, at der er en række udfordringer med at få disse målinger til at fungere som motor for organisatoriske læreprocesser. Den væsentligste handler om, hvordan man omsætter måleresultaterne til forbedrende, 
praktisk handling (Storch m.fl., 2010). Denne udfordring gør sig særligt gældende, når de fænomener, der måles på, ikke har en kausal natur, og man ikke med sikkerhed kan sige, at en bestemt løsning har en bestemt effekt. Inden for det sociale, æstetiske og psykiske område er det vanskeligt at godtgøre almengyldige årsagssammenhænge, da disse i høj grad er kontekstbestemte (Limborg, 2003). Det er derfor ikke så ligetil at løse de påpegede problemer, og det fører til et andet velkendt problem, nemlig at det kan have en decideret negativ indvirkning på trivslen, hvis de påpegede problemer ikke håndteres. Erfaringerne fra en af markedets store udbydere af medarbejdertilfredshedsmålinger peger på, at en positiv sammenhæng mellem deltagelse i tilfredsheds-, trivsels- eller miljøundersøgelser og øget trivsel afhænger af, i hvilken grad deltagerne oplever, at der bliver fulgt op på undersøgelsen (Storch m.fl., 2010), og trivslen falder ligefrem, hvis der ikke er nogen opfølgning, mens den er uændret, hvis der kun følges op i mindre grad (ibid.:47). Noget tyder således på, at der kan opstå en negativ effekt på de involveredes trivsel, hvis de oplever, at de problemer, som undersøgelsen peger på, ikke løses. I forhold til studiemiljøvurderingerne bliver det derfor et vigtigt fokuspunkt at sikre, at der handles på de problemer, der synliggøres via undersøgelsen.

Hvis institutionen er optaget af, at evalueringer skal være læringsorienterede og ikke kun fungere som ekstern legitimering, så er der behov for, at evalueringen skal give mening lokalt. Det fordrer datakvalitet, der afspejler dybden og bredden af de studerendes erfaring med studiemiljøet og dets dynamik samt et rum for, at de studerende kan foretage fortolkning af resultater med henblik på identificering og formulering af behov for forbedring og handleforslag på lokale niveauer i organisationen.

Som alternativ til de rationelle strategier står de dialogorienterede og studenterinvolverende strategier, hvor de berørte direkte deltager i udviklingen af praksis. Sådanne strategier afspejler en social og kulturel organisationsforståelse, hvor læring ses som dynamiske processer, der kan have udgangspunkt mange steder i organisationen (Friche, Keller \& Rasmussen, 2011). I en studenterinvolverende strategi har de studerende ansvar for design, fortolkning, handlingsforslag og implementering. Dette kræver et alternativt evalueringsdesign.

For at styrke studiemiljøvurderingernes effekt som organisatorisk lærings- og udviklingsredskab er det vigtigt, at der målrettet udvælges og realiseres effektive handlinger på baggrund af afdækning af studiemiljøet. Vi vil derfor undersøge udbyttet af at anvende en mere studenterinvolverende metode til studiemiljøvurdering, der mobiliserer de studerende i alle undersøgelsens faser og aktiverer dem ift. at vurdere problemernes vigtighed samt ift. at udvælge og realisere relevante handlinger. Vi har som undervisere understøttet et hold studerende (ca. 20 personer) $i$ at gennemføre en studiemiljøvurdering via gennemførelse af et miniprojekt baseret på problembaseret 
læring (hvor de 20 blev fordelt på 4 grupper), der både indeholdt problemformulering, undersøgelse, analyse, forslag til handlinger og bearbejdning og modning af disse. Data fra de studerendes produkter, fremlæggelser og diskussioner (observationer i 6 timer af holdets afsluttende arbejde) har vi anvendt i en komparativ analyse af resultaterne fra Aalborg Universitets fælles survey, der blev anvendt til at undersøge studiemiljøet for studerende på samme studie og for samme årgang, men på et andet campus (10 studerende). Data fra de to undersøgelser diskuteres i forhold til forskel og lighed mht. 1) processen i undersøgelsesfasen, 2) produktet i form af datakvalitet, tematisk indhold og præcision og 3) organiseringen og ansvarsfordeling særligt i forhold til design og gennemførelse af indsatser. Vores undersøgelse fokuserer både på betydningen af metoden (kvalitativ eller kvantitativ) ift. generering af undersøgelsesresultater, der ligger til grund for bearbejdning og videre handling, samt på betydningen af organiseringen af processen for de studerendes involvering, mestring og empowerment.

\section{Procesdesign}

Det alternative design fandt vi inden for rammen af et miniprojektarbejde baseret på problembaseret læring (PBL) (Kolmos, Fink \& Krogh, 2004; Krogh et al, 2008; Lund \& Jensen, 2011). I PBL definerer de studerende selv deres undersøgelsesgenstand inden for de bredere rammer, i dette tilfælde emnet studiemiljø. De gør dette ved at definere en problemformulering, der bygger på en erkendelse af en anomali eller undren, og denne problemformulering skaber retning i deres undersøgelse, analyse og handleforslag. Det var oplagt at gøre de studerende til forskere i eget studiemiljø, fordi de har forskningskompetencerne til det (i modsætning til mange andre "brugere", "borgere" og "kunder"). En anden vigtig dimension var som nævnt, at vi ville aktivere de studerende, så de ikke blot var leverandører af viden, men også leverandører af løsningsforslag samt aktivt medvirkende til at realisere løsningsforslagene.

\section{Datakvalitet}

For at kvalificere evalueringsprocesser er dataindsamling væsentlig. I den problembaserede læreproces designer de studerende selv en undersøgelse, der kan give svar på deres problemformulering. Inden for en tidsmæssig snæver ramme, vil studerende ofte anvende kvalitative undersøgelsesmetoder som interviews eller observation. Disse undersøgelsesformer kan anvendes eksplorativt og er derfor velegnede, når fænomenet ikke er veldefineret, og relevante sammenhænge ikke er velbeskrevet. De kvalitative metoder bygger tillige på den forstående tilgang til forskning, der ikke søger kausaliteten, men intentionaliteten i menneskelig handling, tænkning og følelse (Karpatschof, 2010). Derudover er det centrale at opnå viden om egenskaber, dimensioner og indre sammenhænge i fænomenet. Denne form for undersøgelse vil ideelt set gå i dybden med et særligt problem inden for studiemiljøet og fremskaffe nuanceret viden om dette problem mht. dimensioner og egenskaber, sammenhænge og 
aktørernes intentionalitet, som de opleves og erfares ud fra aktørernes livsverdensperspektiv.

Dette står i kontrast til kvaliteten af data, der er resultatet af traditionelle surveys, hvor reduktion af livsverdenen er et vilkår, og man altid kritisk kan spørge, om undersøgelsen fanger relevante kategorier, distinktioner og sammenhænge i fænomenet 'studiemiljø', når den samlede livsverden og livsførelse splittes op i fastlagte spørgsmål og svarkategorier. I sin reneste form repræsenterer de kvantitative undersøgelser en forståelse af livsverdenen som kontekstabstraherende, generaliserende (generisk) og atomiserende (Karpatschof, 2010:416), og "herved er det ikke bare personernes særlige individualitet, som forsvinder. Det gør deres særlige sociale kontekst også." (ibid. 413). Det betyder, at surveyresultater ofte skal genfortolkes mht. at udlede relevante erkendelser om sammenhængen mellem resultaterne og individuelle, sociale eller kontekstuelle faktorer.

\section{Empowerment}

Mulighed for selv at fokusere, designe og gennemføre en undersøgelse, analysere resultaterne og formulere handlinger og implementere disse giver de studerende en erfaring med at handle problemfokuseret og aktivt på de udfordringer i miljøet, de oplever. Derved opnår de studerende den positive medlæring af deltagelse i processen, at de selv er aktive aktører i deres studiemiljø og kan påvirke det. I et videre erhvervsperspektiv kan dette ses som en kompetence til at opleve arbejdsmiljø som noget, der til dels er socialt konstrueret, og som man derfor kan påvirke i en vis udstrækning og tage medansvar for udviklingen af. Empowerment forstås således ikke her som en bevidstgørelse af og frigørelse fra undertrykkende samfundsstrukturer (som hos Paolo Freire), men i betydningen mestring (Lazarus \& Folkman, 1992), der er en kompetence til generelt at kunne arbejde aktivt og problemorienteret med de væsentlige udfordringer, man oplever.

\section{Beskrivelse af miniprojektet}

Opgaven var et miniprojekt om studiemiljø over fem arbejdsdage på en kandidatuddannelses 8. semester. De studerende skulle i grupper analysere en selvvalgt problemstilling og udarbejde konkrete, velargumenterede forslag til sikring af bedre studiemiljø for deres hold. Der var afsat et kontant beløb hertil. Projektet afsluttedes med et seminar med præsentation og evaluering af resultater samt valg af hvilke(t) forslag, der skulle tildeles penge til gennemførelse af studiemiljøforbedringen.

I oplægget til og motivationen for arbejdet blev der blandt andet redegjort for den form og metode, der indtil da var anlagt ved studiemiljøvurderinger ved danske universiteter og endvidere deltog en psykolog fra Studenterrådgivningen, som de studerende interviewede. På baggrund heraf diskuterede hver gruppe sig frem til den problemstilling, som de specifikt ønskede at fokusere på. Der blev opfordret til 
at tænke "stort" med ønsker og visioner for det gode studiemiljø og derefter se på, hvorledes de helt konkrete uddannelsesmæssige rammer kunne optimeres.

På projektets 5. dag samledes alle til præsentation af resultaterne samt viderebearbejdning af de enkelte ideer mhp. at skabe konsensus om, hvilke ideer der skulle og kunne realiseres. De fire gruppers resultater blev præsenteret mundtligt suppleret med forskellige medier: Powerpoints, video (lagt på YouTube), 'prezi' (præsentationsværktøj) m.m. Herefter bearbejdede de studerende gennem forskellige processer idéerne med henblik på at udvælge hvilke, der skulle realiseres. Til dette formål blev de studerende introduceret til en metode til indkredsning og valg

Følgende to hovedidéer fremkom: Udvikling af forhallen til et indbydende rum, hvor man kunne spise, arbejde, snakke og hygge samt udvikling af "mentorstafetten", hvor ældre studerende skulle uddannes i konflikthåndtering og anerkendende kultur for at kunne agere som mentorer for yngre studerende; dvs. én løsning der forbedrede miljøet for holdet selv og én løsning, der varetog kommende studerendes interesser. Efter en del diskussion valgte de studerende at fastholde begge idéer, og de blev derefter bedt om at lave handlingsplaner (hvad, hvem, hvornår) for det fremtidige arbejde og anslå udgifternes omfang.

\section{Data fra de studerende}

Vi facilitatorer samlede data gennem observationer af de studerendes proces på sidstedagen samt fra deres produkter (powerpoints, video, prezi). Fire temaer viste sig meget centrale i de studerendes vurdering af og ønsker til et godt studiemiljø:

Tilhørsforhold til studiet kom til udtryk som et centralt tema både helt konkret i forhold til de fysiske rammer: "Hvor hører vi til?" og i forlængelse heraf også i forhold til behovet for socialt og fagligt samvær med medstuderende. Der blev peget på de lokalemæssige forholds betydning, men i videre forstand også tilhørsforholds betydning for både motivation og selvdisciplinering. Tilstedeværelsen af let tilgængelig information og viden om faglige aktiviteter også på andre institutter og miljøer på fakultetet var noget, der ville kunne styrke oplevelsen af at høre til ikke blot på det pågældende studium eller institut, men i videre forstand styrke oplevelsen af at være en del af universitetet.

Et andet centralt tema var faglig identitet. De studerendes søgen efter den faglige profil, de ønsker at forlade kandidatuddannelsen med, betyder spørgsmål som "hvad bliver vi, når vi bliver store?"; "hvad bliver vi gode til?", og en vis forventning om, at studiet kan/skal levere svaret på, hvordan den fremtidige karriere kan se ud. Men hvordan kan man støtte dette på en kandidatuddannelse, der i sagens natur har et bredt sigte? De studerende gav udtryk for, at noget, der kunne styrke deres udvikling af faglig identitet, ville være forskellige former for fysisk repræsentation af insti- 
tuttets faglige identitet, kerneydelser og værdier samt løbende information om nyheder på instituttet (personer, aktiviteter, ansættelser etc.). Viden om underviseres faglige interesser og aktiviteter ville medvirke til at skabe et billede af stedets faglige identitet ligesom tydelige spor af instituttets og uddannelsens historie ville gøre, $\mathrm{fx}$ gennem billeder af tidligere årgange. Informationer vedrørende instituttets og underviseres faglighed, der ligger tilgængeligt på nettet, på instituthjemmesider etc. opleves således ikke som tilstrækkeligt men må suppleres med fysiske repræsentationer, artefakter etc., der anskueliggør, symboliserer og fortæller. I det hele taget var synlighed, tilgængelighed og fysisk tilstedeværelse et tredje centralt tema for et godt studiemiljø. Dette relaterede sig både til underviseres tilstedeværelse og i forhold til kontakten til studerende på andre uddannelser og årgange. Der var et ønske om mere kontakt og relationer mellem studiets årgange og mellem instituttets forskellige uddannelser med henblik på at udnytte mangfoldigheden, og løsningen herpå var den nævnte "mentorstafet".

Endelig var et fjerde centralt tema studiets kultur, både som udtryk for noget etableret, eksisterende, der opleves som usynligt og uhåndgribeligt ("hvilken kultur har vi på dette studie?") - og som ansatsen til at opleve, at man selv kan være medskabende i forhold til studiets kultur. Sidstnævnte blev behandlet dels i forhold til de fysiske rammer som bestemmende for muligheder og begrænsninger ("hvilke fysiske rammer har vi for at kunne danne vores kultur"), dels i forhold til sociale og psykologiske dimensioner ud fra spørgsmålet om, hvordan man kan skabe en positiv og anerkendende studiekultur.

\section{Handlingsperspektivet}

Gruppen med fokus på fysisk indretning af forhallen fik fremskaffet en ekstra sofa og indrettede hyggekroge m.m. De indkøbte en glasmontre til udstilling af institutpublikationer og opsatte bannere om uddannelserne, begge dele mhp. at synliggøre instituttets faglige identitet. De undersøgte endvidere muligheden for at få opstillet en Cola-automat for at styrke forhallen som socialt samlingssted. "Mentorstafet-" gruppen udarbejdede en model for implementering og gennemførelse af forslaget. Her viste det sig sværere at holde momentum og nå frem til en konkret gennemførelse, da det i større grad krævede en indsats, der rakte ud over miniprojektperioden. Det blev tydeligt, at den form for kulturudvikling ville kræve studienævnsmæssig forankring.

\section{Analyse af resultaterne}

Vi har kunnet sammenligne resultatet af miniprojektet med resultatet af universitetets generelle studiemiljøundersøgelse (herefter "survey") på uddannelsens søsteruddannelse på en anden campus. Sammenligningen vil fokusere på tre områder: proces, produkt i form af datakvalitet og organisering. 
PBL-tilgangen betød, at de studerende gik ind i en bred problemafsøgende fase, hvor alt, hvad der kunne være af betydning for studiemiljø, potentielt kunne vælges som fokuspunkt. Derpå blev den eller de problemfelter, som oplevedes som mest påtrængende, udvalgt til nærmere undersøgelse. Denne tilgang understøttede således en fokusering på og dyberegående bearbejdning af samt vidensgenerering om de pågældende problemstillinger. Den kvalitative tilgang betød, at de studerende fik nuanceret viden om den kompleksitet, et studiemiljø udgør med et samspil af sociale, psykiske, kulturelle og fysiske faktorer. Dette viste sig i de studerendes unders $\varnothing$ gelsesdesign, der både indeholdt kvalitative og kvantitative metoder og data (fx systemdata, spørgeskemaer, interviews), ligesom de foreslåede forandringstiltag også rummede sociale, psykiske og kulturelle dimensioner.

I generelle, kvantitative studiemiljøundersøgelser vil institutionens opfattelse af, hvad der er vigtigt i et studie- og læringsmiljø, præge spørgsmål og besvarelser. I det aktuelle survey blev de studerende bl.a. bedt om at vurdere, om den fysiske indretning var stimulerende for læring og samarbejde, om it-faciliteterne var tilfredsstillende, om muligheden for at finde relevant studiemæssig information var til stede, underviseres og vejlederes engagement $i$ de studerendes faglige udvikling samt faciliteter for pauseaktiviteter, det vil sige mange af de forhold som de studerende i miniprojektet også var omkring af egen drift. Der var mulighed for yderligere kommentarer, og de studerende blev til slut bedt om at prioritere tre områder, som ville forbedre deres trivsel.

Rammerne for de to processer var således vidt forskellige: Den individuelle studerendes besvarelse af et spørgeskema med en arbejdsindsats på max. 30 minutter, og et intensivt aktionsforskningslignende projekt over fem dage udført i en gruppe af studerende i en læringsoptik og med et fælles udviklingsperspektiv. Miniprojektet var med andre ord præget af kollaborativ udforskning, vidensgenerering og problemløsning, mens surveyet overvejende var præget af ikkeforberedt, individuel stillingtagen.

Med så forskellige rammer måtte det forventes, at produktet i form af datakvalitet også ville være forskelligt. De studerendes præsentationer som afslutning af miniprojektet udgjorde et righoldigt, multimedialt og nuanceret datamateriale om oplevelse af studiemiljø, behov og ønsker til et studie- og læringsmiljø samt ikke mindst de studerendes konkrete prioriteringer af indsatsområder.

I surveyet gik de studerendes prioriteringer alt overvejende på forbedring af fysiske forhold, undervisningslokaler og fysiske rammer til pauseaktiviteter, samt it. Derudover nævntes konkrete forslag: Fx "Udstillinger, spor af liv på væggene", "Mere info og overblik fra studiesekretæren", "Socialt fællesskab, fx fælles fredagsbar og arrangementer som fyraftens- foredrag eller gæsteforelæsere", og "... hvis man gerne vil 
have mere studieliv efter undervisning, kan man med fordel arbejde på at få det mindre klinisk på gangene. Sætte lidt sofaer op, lidt automater med kaffe og lign."

Om end der i de kvalitative udsagn i surveyet kommer mere nuancerede beskrivelser frem og også peges på forbedringsforslag til de fysiske rammer, lægger formen ikke op til den dyberegående og mere holistiske vurdering af og refleksion over betingelser for studie-/læringsmiljø, som de studerende nåede frem til gennem deres miniprojekt. Selv om der nævnes et ønske om "sociale fællesskaber", fremgår det eksempelvis ikke, hvor stort dette ønske er, og om de stillede forslag ville være de bedste løsninger. En distancerende formulering som "... hvis man gerne vil have mere studieliv efter undervisning..." efterlader således også tvivl om, hvorvidt det er udtryk for et stærkt ønske fra studerende.

Sammenligningen mellem de to typer data viser, at temaer som faglig identitet, kultur, synlighed, tilgængelighed og tilhørsforhold, som viste sig centrale for de studerende i miniprojektet ligesom de udfoldede beskrivelser af tiltag til løsning af problemerne, ikke kom frem - eller blot blev antydet - i søsteruddannelsens survey. Der er således betydelig forskel i datakvaliteten mht. indhold og præcision.

Selve organiseringen af forløbet betød, at prioritering af indsatsområde og udformning af konkret løsning lå entydigt hos de studerende. Oplægget var, at dette ikke var et hypotetisk "lade-som-om-" projekt, men noget der skulle føre til konkret forandring, og at de studerende forventedes at tage ansvar i processen og handle på undersøgelsesresultaterne.

Surveyet rummer som tidligere beskrevet en lige så klar ansvarsfordeling, hvor undersøgelsesdata behandles og fortolkes i de relevante organer, og der udarbejdes en handlingsplan. Citatet "... kan man med fordel arbejde på ..." viser, at man som studerende forventer, at det er andre, der skal agere for at skabe forandring. Sammenlignes dette med "indretningsgruppens" handlen på ønsket om sofa og automat i miniprojektet, fremgår her, hvilken forskel organiseringen betyder for oplevelsen af rolle og handlerum. Et tilsvarende eksempel udgør ønsket om "sociale fællesskaber på campus, evt. til andre studerende", som udtrykkes i surveyet. I miniprojektet førte et lignende ønske til udvikling af en konkret model for interaktion og etablering af socialt fællesskab, nemlig "mentorstafetten".

Organiseringen betød således, at de studerendes rolle i miniprojektet blev transformeret fra blot at være informanter - eller leverandører af data - om deres studiemiljø for andre at agere på til at være aktive og involverede i selv at følge op på det og skabe forandring. 


\section{Kritisk efterrefleksion}

Vi har ovenfor vist, at hvis man sammenligner de to typer undersøgelser mht. resultat og proces, så er de forskellige på en række områder mht. hvilken viden, de genererer om faktorer og sammenhænge i studiemiljøet, samt i hvilket omfang de aktiverer de studerende i udviklingen af studiemiljøet. Miniprojektet skabte kvalitative og kontekstualiserede resultater, og de konkrete forslag var vigtige for udvikling af studiemiljøet hos den konkrete gruppe studerende. Derimod er det tvivlsomt, om de konkrete resultater kan generaliseres direkte til andre studerende. Styrken i miniprojektet som studiemiljøvurderingsmetode ligger i, at den skaber lokalt relevante resultater og handlingsforslag, der kan realiseres direkte. Det betyder samtidig, at metoden har en række svagheder. Hvis de studerende accepterer rammesætningens præmisser og fokuserer på forhold, som de mener, at det er realistisk at ændre på, vil der være en bias i forhold til, hvad de vælger at fokusere på og arbejde videre med, som beror på deres forestilling om organisationen og deres rum at agere i. Vigtige og centrale problemstillinger vil blive valgt fra indledningsvist, fordi de studerende ved, de ikke har direkte indflydelse på dem. Dette vil typisk være faktorer i det fysiske eller teknologiske studiemiljø, da beslutninger om udviklinger i disse kræver mere omfattende og længerevarende beslutningsprocesser. I kvantitative studiemiljøundersøgelser vil man som respondent ikke være begrænset af hensyntagen til de konkrete rammer, hvilket understreger betydningen af forskellige undersøgelsesmetoder til at indfange kompleksiteten, når et studiemiljø skal vurderes.

Denne undersøgelses resultater peger på, at hvis universiteter og andre læreanstalter vælger at gennemføre studiemiljøvurderinger via surveys, så har de tre udfordringer:

- $\quad$ at få tilstrækkeligt nuanceret viden om særligt de æstetiske, sociale, psykologiske og kulturelle dimensioner af studiemiljøet, således at resultaterne afspejler de studerendes reelle oplevelse af studiemiljøet.

- at få resultater, der er tilstrækkeligt lokale til, at det gør en forskel i de konkrete miljøer, hvis der handles på dem og

- at få involveret de studerende i en grad, så de oplever, at de har indflydelse på og er aktører i udviklingen af deres eget studiemiljø.

Disse udfordringer kan løftes ved at supplere surveys med aktiviteter à la miniprojektet, men de kan naturligvis også løftes på mange andre måder. Pointen er, at enhver tilrettelægger af studiemiljøvurderinger bør reflektere over og håndtere de tre udfordringer, således at processen kan føre til de studerendes aktive involvering i udvikling af de lokale studiemiljøer. 


\section{Konklusion}

Erfaringer fra trivsels- og arbejdsmiljøundersøgelser på arbejdspladser har vist visse vanskeligheder med at omsætte surveyresultater til forbedrende handlinger. Da studiemiljøvurderinger har mange fællestræk med denne type vurderinger, er det nærliggende at antage, at lignende problemer kan gøre sig gældende på universitetet. Vi valgte derfor at gennemføre studiemiljøvurderingen i en alternativ organisering som miniprojekt funderet i problembaseret læring. Denne organisering gav mulighed for at generere kvalitative data, fokusere undersøgelsen, vurdere vigtigheden af problemtikker og udvikle handleforslag. Derudover lagde vi op til, at de studerende skulle være drivende i implementeringen af handleforslagene.

I en sammenligning af miniprojektet med resultaterne fra søsteruddannelsens survey, kan man konstatere en række forskelle i proces, datakvalitet og organisering. Miniprojektorganisering betød, at de studerende gennemførte alle faser af forandringsprocessen i en løbende proces, og at der blev skabt tæt sammenhæng mellem de udpegede problemområder, løsningsforslag og implementering, samt at problemer og løsninger var funderet i den lokale og specifikke kontekst. Processen fik karakter af en søge-læreproces for de studerende, og flere løsningsforslag havde et vist element af nytænkning. Denne involvering står i kontrast til de studerendes rolle som leverandører af information i surveyet. Mht. datakvaliteten målte surveyet primært de studerendes oplevelse af deres fysiske/tekniske miljø (9 spørgsmål ud af 19), mens 1 spørgsmål gik direkte på det sociale miljø. I miniprojektet lagde de studerende størst vægt på sociale og kulturelle miljøfaktorer, og det fysiske miljø blev inddraget som middel til at skabe socialt tilhørsforhold ikke blot til medstuderende, men også til de større faglige praksisfællesskaber på instituttet. En anden forskel var den righoldighed i beskrivelsen af studiemiljøet, som den kvalitative metode fik frem, samt den nuancerede viden projektet genererede omkring samspillet mellem sociale, psykiske, kulturelle og fysiske faktorer. Mht. organiseringen af forløbet var der klare forventninger til, at de studerende selv skulle implementere deres forslag, mens der i surveyorganiseringen er nedlagt en forventning om, at besluttende fora handler på resultaterne. Processen førte til, at de studerende formåede on-the-spot at skabe vigtige forbedringer i deres eget fysiske studiemiljø, der betød at pausefaciliteterne efterfølgende blev mere benyttet, hvilket formodes at have en positiv effekt på de sociale og faglige aspekter af studiemiljøet. Derudover resulterede søge-læreprocessen i en række nytænkende ideer, hvoraf de studerende valgte at arbejde videre med "mentorstafetten". Den vigtigste læring var dog den medlæring i form af kompetence til at undersøge, vurdere og handle ift. sit miljø, som de studerende opnåede.

De forskellige metoder giver tydeligvis forskellige resultater og indebærer store forskelle i de studerendes involvering. For både at kunne håndtere udfordringer, som 
bedst bæres igennem via studenterinvolvering, og andre, som kræver institutionsmæssig forankring gennem behandling og ressourcetildeling i besluttende fora, peger en samlet konklusion i retning af, at man med fordel kan anvende forskellige undersøgelsesmetoder i studiemiljøvurdering.

Hanne Dauer Keller er cand. psych., ph.d. og lektor ved Institut for Lxring og Filosofi på Aalborg Universitet. Hun forsker og underviser i læring og udvikling $i$ arbejdslivet herunder evalueringsredskabers muligheder for at fremme forandringer.

Annie Aarup Jensen er cand.mag., ph.d. og lektor ved Institut for Læring og Filosofi på Aalborg Universitet. Hun forsker og underviser $i$ læring og pædagogik, herunder problemstillinger relateret til kultur og læring, voksnes læreprocesser samt uddannelsesudvikling inden for Higher Education.

\section{Referencer}

Friche, N., Keller, H. \& Rasmussen P. (2011). Evaluering som organisatorisk læring. I Andreasen, K., Friche N. \& Rasmussen, A. (red.). Målt og vejet-uddannelsesforskning som evaluering. Aalborg: Aalborg Universitets Forlag.

Jacobsen, D. I. \& Thorsvik, J. (2008). Hvordan organisationer fungerer. Indføring i organisation og ledelse. København: Hans Reitzel.

Karpatschof, B. (2010). Den kvalitative undersøgelsesforms særlige kvaliteter. I Brinkman S. \& Tanggaard, L. (red.). Kvalitative metoder: En grundbog. København: Hans Reitzel.

Kolmos, A., Fink, F. K. \& Krogh, L. (eds.) (2004): The Aalborg PBL Model. Aalborg: Aalborg University Press.

Krogh, Lone m.fl. (red) (2008). Projektpædagogik. Aalborg: Aalborg Universitetsforlag.

Lazarus, R. \& S. Folkman (1992). Stress, appraisal, and coping. New York: Springer.

Limborg, H.J. (2003). Risiko og forebyggelse i 'det nye arbejdsliv' set i et arbejdsmiljøperspektiv. I Tidskrift for arbejdsliv nr. 3.

Lund, B. \& Jensen, A. A. (2011). Framing of Collaboration and its Impact on Creativity and Innovative Skills. I Communication, Collaboration and Creativity: Researching Adult Learning. Marianne Horsdal (ed.). University Press of Southern Denmark, s. 145-160.

Storch, m.fl. (2010). Resultatorienterede medarbejderundersøgelser: fra gennemsnitlighed til unikhed og processerne der gør en forskel. København: L\&R Business. 